\title{
Information accessibility and use as correlates of women political participation in the Niger delta region of Nigeria
}

\author{
Eteng Uwem ${ }^{1, ~ *, ~ O p e k e ~ R . ~ O . ~}{ }^{2}$ \\ ${ }^{1}$ Acting Institute Librarian, Nigerian Institute of Advanced Legal Studies, University of Lagos Campus, Lagos, Nigeria \\ ${ }^{2}$ Dept. of Information Resource Management, Babcock University, Illisan, Nigeria
}

Email address:

uwemet@yahoo.com (Eteng U), rosalineade@yahoo.com (Opeke R. O.)

\section{To cite this article:}

Eteng Uwem, Opeke R. O.. Information Accessibility and Use as Correlates of Women Political Participation in the Niger Delta Region of Nigeria. Psychology and Behavioral Sciences. Vol. 4, No. 1, 2015, pp. 5-17. doi: 10.11648/j.pbs.20150401.12

\begin{abstract}
Information is a crucial ingredient for political participation. A lack of relevant, accurate and timely information may lead to poor or non-participation in the political process. Women in Nigeria are known for their low level participation in politics. Demographically they are more than men but their number fails to be translated to political strength. Recent survey shows that women constitute majority of voters but score very minimal success in political gains. They occupy very scanty leadership positions and are grossly underrepresented in the strategic height of politics. Women are also checked by cultural and traditional definitions. This paper concludes that lack of relevant information is responsible for this unwholesome state of their political position being so highly circumscribed. The paper recommends development of policies and intervention strategies that will improve the political information environment of women bringing about a more inclusive representative governance with implication for sustainable structural change leading to the generation of a more participative society.
\end{abstract}

Keywords: Political Information, Political Participation, Information Accessibility and Use, Women, Niger Delta

\section{Introduction}

Women political participation and information needs and services have been a major concern and challenge to the international community for decades. This is as a result of awareness of women's relatively high risk of exposure to inaccurate and segmentary information about political issues, such as: politics is too dirty a game for women, politics is generally not a woman's turf, politics is characterized by high political virility so only the stout minded could dare, (most often, this stout minded are men), women should only be seen and not heard, women are cooperative subordinates socially, economically, politically; they are homemakers and should tend only to the home fronts, they should be wives and mothers to their husbands and their children in the private sphere and leave political play in the public sphere for the men. This background paints a total picture of discrimination of women in political sphere in spite of the generally acknowledged facts that women limited or nonparticipation in the political process guarantees not only underdevelopment but truncates real progress towards equality, development, justice and peace.

Over time issues of human right as concerned women discrimination have resonated with the conscience of international communities. Various international instruments and their protocols therefore have supported equal participation of women in development as part of an integral effort to build institutions on equity and justice. The right to access and use of information becomes a tool in this political transformation; it helps ensure that governments are accountable and promotes development through improved governance and public participation. The associated increase in political information is often seen as implying increase in political involvement. In this spirit studies in political economy have advanced the existence of a positive link between information provision and women political participation. The first world conference on status of women convened in Mexico in 1975 together with the UN Decade for Women (1976-1985) launched a new era on global politics to promote dialogue on gender equality. The women conference held in Copenhagen, Denmark 1980; the 1985 Women Conference in Nairobi; Vienna Convention of 1993, the Beijing Conference of 1995 for gender equality; all emphasized the need for women to have access to information and services that will enhance their political emancipation/rights through gender equality and promote their political awareness. 
Other international instruments also recognize the rights of women to receive information and services necessary for full integration into politics - the (UDHR 1948). The Universal Declaration of Human Right provides legal articulation for these rights -The International Covenant on Civil and Political Rights (ICCPR 1976) defines the rights to equal political participation. Nigeria also signs the Protocol to the African Charter on Human and Peoples 'Rights on the Rights of Women in Africa, which, together with the ICCPR, prohibit discrimination against women in the exercise of their rights to vote, Convention on the Elimination of All Forms of Discrimination Against Women (CEDAW 1979). Article 5 of CEDAW calls upon states to make every effort to remove gender stereotypes rooted in traditional practices and world view. Even the UN member states have shown their support for the advancement of women's political participation and leadership. The General Assembly at its fifty- eighth session in 2003 adopted resolution 58/142 and resolution A/RES/66/445 of September 16, 2011 on women and political participation which urged government, the UN system, NGOs and other actors to develop without hesitation, a comprehensive set of policies and programmes to increase women participation in decision making (UN Report 2005). These resolutions have been described as major steps forward for advancing women's political participation on equal platforms.

Recent years have witnessed an increasing awareness of the status of women's rights and gender equality on the African continent as a whole as reflected in these important commitments related to women's political participation which include: Article 4 (1) of the Constitutive Act of the African Union, the Dakar Platform for Action (1994); the African Plan of Action to Accelerate the Implementation of the Dakar and Beijing Platforms for Action for the Advancement of Women 1999; the Protocol to the African Charter on Human and Peoples' Rights on the Rights of Women in Africa (2003); The ECOWAS Protocol on Democracy and Good Governance; The NEPAD 2001 framework; Harare Commonwealth Declaration of 1991 and the African Union's Solemn Declaration on Gender Equality in Africa 2004 (Heynz 2010; African Union Constitutive Act;Draft 2 - The African Union Gender Policy 2002; EU Election Observation mission 2007).

These treaties invariably backed the need for information provision to educate the women on their political rights, aspirations, duties, obligations to be able to face the challenges for increased political participation clamored for by these treaties. Of note, is the International Knowledge Network of Women in Politics (which is an online network, jointly supported by the five partner organizations, that aim to increase the participation and effectiveness of women in political life by utilizing a technology-enabled forum to provide access to critical information resources and expertise, stimulate dialogue, create knowledge, and share experiences among women in politics. (iKNOWPolitics, 2005)

Participation of women in decision making bodies on equal terms with men is guaranteed in Nigeria's Constitution.
Section 17 (1) (2) of the 1999 Constitution of the Federal Republic of Nigeria states 'that every citizen shall have equality of rights, obligation and opportunities before the law'. Section 42 (1) of The Nigerian Constitution frowns against discrimination on the grounds of sex and invariably backs the provision of information to women in political space to reverse this undesirable trend. To this end, government of Nigeria, civil or military and offices of the First Ladies, have established organs and initiated programs and actions at sensitizing women towards national development. The essence of such bodies, agencies and policy programs such as Better Life For Rural Women (BLP) initiated by President Babangida, Family Support Program (FSP) by President Abacha, National Orientation Agency (NOA) later MAMSER, National Commission For Women (NCW) by President Olusegun Obasanjo, later upgraded to a ministry (Ministry of Women Affairs) with a woman affairs minister and so on, was to facilitate gender equality through economic growth, democracy and good governance and stimulate interest in gender related issues and national development through effective information dissemination. These bodies operated the responsibility of organizing and educating women at grassroots for political activism, that is, enlighten women on the limitless opportunities opened to them should they participate in the political process.

\subsection{Statement of the Problem}

Gender discrimination remains pervasive in every dimension of life activities worldwide. Gender gaps are widespread in access to resource control in economic opportunities, social and even in political sphere. Access to appropriate political information by women in the Niger Delta region is crucial to the achievement of the Millennium Development Goal (MDG) of achieving gender equality (that is, partaking equally in the shared values of the state reflected in national and international policies) and empowerment of the most excluded group from political development. Yet literature has shown that women have inadequate access to political information due to socio-cultural values, geographical variables, economic factors and uneven educational development.

Perhaps women's inadequate access to political information could have promoted ignorance of common basic political problems that may have hindered women political participation. In other words, can inadequate access to and use of political information among women be linked to political participation in the Niger Delta Region of Nigeria?

It would be imperative therefore that an investigation be carried out to determine the influence of political information accessibility and utilization on political participation among women in the Niger Delta Region of Nigeria

\subsection{Objectives of the Study}

The main objective of the study is to examine the extent to which access to and utilization of political information predicts the political participation of women of the Niger 
Delta Region of Nigeria. The specific objectives of this study are to:

1. ascertain how women in Niger Delta region participate in politics;

2. ascertain the condition that will promote the level of information accessibility for women's political participation in the Niger Delta;

3. ascertain the condition that will promote information use for women's political participation in the Niger Delta;

4. determine the level of use of information for politics by women in the Niger Delta Region;

5. examine the relationship between information accessibility and women's political participation in the Niger Delta;

6. determine the relationship between information use and women's political participation in the Niger Delta;

7. investigate the composite relationship of political information accessibility and utilization on women in political participation; and

8. find out challenges faced by women in accessing information for political participation in the Niger Delta;

\subsection{Research Questions}

In order to achieve the objectives stated above, the following research questions are posed:

1. What is the level of women political participation in the Niger Delta?

2. To what extent do women in Niger Delta have access to political information?

3. To what extent do women in Niger Delta use political information?

4. What are the constraints to access and use of political information among women in the Niger Delta Region?

\subsection{Significance of the Study}

The findings of this study will provide empirical evidence on the state of participation of women from the Niger Delta Region, in politics and how this participation has been promoted or hindered by their ability to access/use information. The result of this study will bring to fore the political information needs of women activists in the Niger Delta particularly and in Nigeria/Third world countries in general, who would want so much that their votes be counted and their voices heard. Government and related NGOs concentrating on women status in armed conflict zones, women studies in politics like United Nation Development Fund For Women in Nigeria (UNIFEM), Women For Democracy and Leadership (WDL), BOABAB, Women In Nigeria (WIN), Women for Democracy (WD), Women Optimum Development Foundation (WODEF) will be expected and provoked by this study to make spirited efforts to meet these needs.

The study will be beneficial to the nation who would use the recommendation of this study to educate and motivate women to participate in the political decision making process that affect them. This will increase the clamor for peace, justice and even renewed faith in the system that will give legitimacy to the institution of governance/ political system.

Finally, findings for this study will contribute to knowledge and literature on women political information and will no doubt be of immense help to research into women activism.

\section{Conceptual Framework}

This study explains the process by which the study will be carried out indicating how the variable accessibility and use interact to affect political participation of women in the Niger Delta Region of Nigeria. Accessibility and utilization are independent variables while political participation is a dependent variable. The degree of political participation is dependent on political information access and use by women in politics. Accessibility promotes utilization. In this vein, the access and use of information by women in political participation is affected by literacy level, channel through which information gets to the women, nearness to information sources, cost of information acquisition, relevance, confidentiality in information sources, level of detail, understandability of information choices. The effect of these variables put together shows that political information access and use will predict women political participation. Put differently, women political participation is a function of access and use of political information.

\subsection{Structures that Undermine Women Political Participation}

Women constitute a little above $50 \%$ of the world's population. They suffer all kinds of discrimination in economic, social, cultural and political spheres. The Human Development Reports show that women are the greatest excluded group from development (UNDP 2005). They are, by implication, not possessing the same skills as men to navigate the turf political arena. Reasons, too many, have been advanced for this heightened exclusion of which one is the existence of a patriarchic structure. Fundamentally, patriarchy promotes men's insistence to power and sets back the cause of women's rights leading to greater rigidity and marginalization. Women must operate under male style politics and under this arrangement, are socialized to meek roles like caring for the homes, rearing and looking after children, satisfying the sexual needs of men, working the fields, farming, cooking. Women are interdependent and cooperative while men generally exhibit political pattern of independence and hierarchical power (Ademiuyi \& Ademola 2004; Bari 2005).

Women are constrained by norms, beliefs, customs and values, discriminatory structural systems, inequitable division of labour, cultural attitudes, traditional precincts, and limited opportunities for gender mainstreaming, undemocratic electoral systems are some reasons which subjugate women and limit their representation in public life. The specific ways in which this operates vary culturally and 
over time. At one time it can manifest as inadequate access to education, at another time as domestic violence and even as male dominated decision fora and women inferior access to assets of many kinds including non-access to information resources (Mosedale 2005; Nwosu et al 2012). Current estimates show that women labour is undervalued, they operate a lower mobility than the men, their numerical strength is not at parity with political strength hence they are under-represented in the strategic height of politics and therefore participate less favourably in the overall policy decisions that affect them. To date, women in Nigeria are very far from having changes in their political fortune. The absence of women in decision-making position defeats the equality clause implied in the Nigerian Constitution. Thus, there is a gap between the formal idea of women's participation and their meaningful use of power. (Agbalajobi2010; Arowolo 2010).Subsequent general elections in Nigeria witnessed a heightened increase in women voter turnout, there was increase in women aspirants and contestants yet a negligible number actually won elections.

Table 1. The Standing of Nigerian Women in Political Participation and Performance from 1999 till Date.

\begin{tabular}{|c|c|c|c|c|c|c|}
\hline $\mathbf{S} / \mathbf{N}$ & Position & No. of Available Seats & $\begin{array}{l}\text { No. of Women in } \\
1999\end{array}$ & $\begin{array}{l}\text { No. of Women in } \\
2003\end{array}$ & $\begin{array}{l}\text { No. of Women in } \\
2007\end{array}$ & $\begin{array}{l}\text { No. of Women in } \\
2011\end{array}$ \\
\hline 1. & Presidency & 2 & 0 & 0 & 0 & 0 \\
\hline 2. & Senate & 109 & 3 & 4 & 8 & 7 \\
\hline 3. & House of Reps. & 360 & 12 & 23 & 26 & 26 \\
\hline 4. & Governorship & 36 & 0 & 0 & 0 & 0 \\
\hline 5. & Deputy Governorship & 36 & 1 & 2 & 6 & 3 \\
\hline 6. & 36 States Houses of Assembly & 990 & 12 & 38 & 54 & 62 \\
\hline
\end{tabular}

Source: Lance-Onyeiwu, Maureen (2011). Excerpt from UN Women's Preliminary Analysis of the Results of the2011 General Elections in Nigeria

Table 2. Current Representation of men and Women in Election Positions (2011).

\begin{tabular}{llll}
\hline & Men & Women & Total \\
\hline President & 1 & 0 & 1 \\
Vice President & 1 & 0 & 1 \\
Senate & 102 & 7 & 109 \\
House of Reps. & 334 & 26 & 360 \\
Governor & 36 & 0 & 36 \\
Deputy Governor & 33 & 3 & 36 \\
States Houses ofAssembly & 928 & 62 & 990 \\
& 1435 & 98 & 1533 \\
\hline
\end{tabular}

93.60731, 6.392694

Source: Lance-Onyeiwu, Maureen (2011). Excerpt from UN Women's

Preliminary Analysis of the Results of the 2011 General Elections in Nigeria

2011 election witnessed money politics and magnified the institution of god father ism in Nigerian politics. Irabor (2012) refers to this disturbing phenomenon thus' strong economic base is a strong factor in electioneering campaign given the politics of money that pervades our political landscape'. Most women attained political standing due to kinship affiliations and the credentials of quite a number of the female candidates reflect this view while a lot more other women cannot break into this money politics for lack of sponsorship, poverty and unemployment is rife among women. Nigerian political landscape is characterized with violence, kidnappings, high virility which inhibits women political participation; they are confronted with predetermined sex roles; they are likely to be more illiterate than the men Attoe (2013); Wieringa (2005); they suffer multiple effect of violence, exhibit high level of political exclusion Adebowale (2012)and their lower mobility (relative to men) implies that they often have less information about politics (Pande 2011; Karp\&Banducci 2008).

The political landscape in Nigeria has women lacking political backing and confined to private sphere, stripped by the very society that should accommodate their political views, desires, needs, demands and support to constituted political structure. Public policy carries the male characteristic that sets back the cause of women's rights pushing them further down the lower rung of the political ladder. Many women, especially in the developing countries believe that candidature of a particular election is predetermined; candidates are imposed without popular appeal so their votes will make no difference and they could care less about the quality of government. This lackadaisical attitude is observed as typical of women voting behaviour where many of them who are of voting age feel unconcerned about going for voting or get involved in any other political process.

The public private divide remains as the foundation of the various forms of world democracies (Shirin, 2000,). This dichotomy further tears downs, entrenching a deep divide on gender views of politics. Women are divinely ordained to domestic roles in the private sphere because of their suitability in the homes as wives and mothers, and men ruled the public sphere operating the decision making machinery totally excluding women. With this decline, Kelly \& Burges (1998) observed that women are more likely than men to develop an alternative view of politics, a view that deemphasizes control over others; that dwells in those things that unite rather than divide. They are more likely to develop in other words, a politics based on connectedness and mutual words. One justification why women develop alternative view of politics is that 'women enter politics within this patriarchal context of modern democracies, they are unable to play a role to radically change the sexual politics, rather, they largely play political roles on male's terms. The fundamental assumption in liberal democracies needs to be changed in order to create genuine political space for women within (Bari 2005, Nabanech, 2014). 
Although, some countries witness reasonable women's political awareness and participation, women still have social constraints. Bari (2005) writes that the structural and functional constraints faced by women are shaped by social and political relations in a society. The common pattern of women's political exclusion stem from

(a) social and political discourses

(b) political structure and institutions

(c) socio-cultural and functional constraints that put limits on women's individual and collective agency.

Other authors Losindilo (2010); Ige (2010); Duke II (2010); Effah Attoe (2002); Waring (2010); Tripp [n.d]) enumerated the social constraints to women political participation to include:

a) poor perception by the society that politics belong in the public domain where women should not thread.

b) male domination of politics, political parties and culture of formal political structures.

c) lack of confidence of the electorate on the political competence of women.

d) women lack access to and ownership of productive resources limiting the scope of their political work.

e) quest for power rather than representation.

f) lack of political will on the part of the women because of societal stereotype on politics.

g) lack of resources, political experience, education and political connections to run for office.

African continent among others records the lowest level of women participation in politics, scanty successes not withstanding and of course, the struggle to bring to fore women issues and politics on national and international premise cannot be ignored. Tripp (n.d.) accepts that although the driving force for these changes has been internal, international pressures and norms have given added impetus to these new demands. For example, at the UN Beijing Conference on Women in 1995 the International Parliamentary Union (IPU), the world organization of national parliaments addressed the low rates of female representation in Africa and adopted a Plan of Action to address the reality that men dominate political and parliamentary life in all countries. One of the proposals adopted by the IPU included affirmative action measures to be advocated on a strictly interim basis. Quota systems, in the IPU proposal, states should promote a situation where neither sex occupies a disproportionate number of seats relative to their percentage in the population. With response to the UN initiative, National Gender Policy was adopted in 2007 by the Federal Government of Nigeria formulated to promote a $35 \%$ affirmative action in political space, a policy that demanded $35 \%$ involvement of women in governance to incorporate women into national development as equal partners in decision making - a key strategy to promote gender imbalance in politics. The National gender policy and other affirmative action measures, example, the quota system, equality clauses in the constitutions and all national legislations ( citizenship laws, labor laws, criminal laws, land rights/inheritance laws were aimed at providing women with appropriate factual information on negotiating instruments for concession on good governance. On the African continent, the African Union Constitutive Act is leading example in this regard as it has not only enshrined the parity principle but requires the African Union to have 50\% representation of women commissioners. These appear to be major steps towards breaking the cycle of discrimination in politics which hitherto promoted ignorance and vulnerability to gender participation.

\subsection{Political Information and Women Participation}

Everyone in the society needs information to function effectively. Access to such information is a pre-condition for its use. This is why any serious efforts to promote women's participation in politics must pay attention to the political information environment of women. Women need information more than ever to keep themselves informed and to inform others about proper political integration so that with more of them in politics there will be participation in the decisions that affect their lives. The major function of political information is to increase women's political knowledge, reduce their level of political passivity and skepticism, widen their scope of political views, sharpen their articulation and focus, equip them mentally, socially, psychologically to the vicissitudes of political activities (Uhegbu 2004, Iwara 2010).Additional qualification of political information is that it broadens the range of political choices opened for women involvement (Opeke,2003).

Information for women in politics is a core value for sustained structural change. Information is an important resource. It is as important in the political process as it is indicative.It is a veritable resource; a key ingredient in everyday living, a basic right; it is a key currency in the political process, public policies, and institutionalization. Information is now being bought and sold as a commodity for development. It is a variable whether in policy development, research, advocacy, resource allocation, planning, implementation or political program monitoring.

Political information is well established in the literature of political history as any information which is aimed at informing on political matters such as voters registration exercise, petition writing, how to thumbprint, election time and venue of election, sponsoring of candidates for election, name of candidates vying for offices, laws governing election malpractices, how to identify party symbols, counting of votes, demonstrations, mass mobilization, ability to take part in the conduct of public affairs and so on. Political information enables one to be able to post queries of specific interest, make contacts with representatives without temporal limits imposed by non-access thereby promoting more involvement.

For effective participation in the political process every woman should be armed with the right information. Okiy(2003) noted that for information to truly sensitize women, arouse their interest, strengthen their willingness and enthusiasm to participate in politics, it should be provided at the right time, in the right quality and in the right quantity. It 
should be allocated the highest precision to make it appropriately packaged and properly disseminated in such a way that its availability and utilization will be possible. It should be relevant to them and clearly targeted. It should be provided to women in the language understandable to them. It should be clear in content, localized and devoid of ambiguity. The means by which this information gets to the women should be easy and cheap to use (Uhegbu 2004; Iwara 2010; Nwosu et al 2012; UN Division for Advancement of Women (DAW) 2005).

Political information seeks to empower women to identify and make their choices on their own behalf and to influence the direction of change through the ability to gain control over situations that affect their lives (Arowolo 2010, Bari 2005). Political information is therefore a central variable in identifying the rights of women participation in political structures, in processes where decisions are made regarding the use of societal resources generated by both men and women. It seeks to empower women through distribution of power within as well as in relation to other societies. Numerous theories have shown that voters with more information behave fundamentally differently from those with less ("The value of information in this case is the difference between making informed and uninformed decisions Babalola (2012) and that political participation will fail to establish legitimacy in an environment of hindered information flow (Pande 2011).

According to Kelly (2011) political participation requires information, at a minimum, information is needed to identify choices and their consequences in the political process to establish faith in the system and increase political knowledge.

Opeke (1993) submitted that:

"The major function of political information is not only to enhance the performance of politicians and the overall political process but also to increase the knowledge of the voter, to reduce the variety of choices available to him. If everybody possessed perfect knowledge of his political information needs, as basic to decision making, then perfect knowledge will be guaranteed."

Political information must possess and display relevance, comprehensiveness, timeliness, availability, accessibility and adaptability (Omekwu 2013).

Men and society have realized more than ever before the criticality of information for development. More importantly, the area of women empowerment brings in the aspect of mainstreaming of gender concerns and collating of gender desegregated information analysis in governance which Browne (2014) is so passionate about. This will help set institutions for monitoring development. No society can aspire to greater heights economically, socially, politically and technologically without unhindered information flow (Uhegbu 2004). (http://www.Iknowpolitics.org) reported that though women go through the struggles of funding for campaigns and societal and cultural context which they operate, what is increasingly added to this list is that women often face more difficulties when it comes to seeking out information that might be relevant to their political objectives. In the reflex to take needs or concerns up with local actors, to request information on issues that are important to them, or to engage with constituents by taking part in debates, liaising with civil society or consulting experts, something is often missing

"The missing link ... has been the absence of an effective mechanism for mobilization and stimulating them into action with a view to addressing their problems. That missing link is the lack of information in the right quality and format."(Saleh \& Fatimah, 2011.)

Today in both developed and developing nations information is bought and sold as a commodity of trade. It is the life wire of societies and of government. It is the basis of decision making and decisions could be as good as the information on which they are based (Anyanwu 2011). Political information, according to Bimber (1998) has already acquired political significance as increasing number of citizens' use it to learn about government policies and actions, discuss issues with one another, contact elected officials, obtain voters registration and other information that can facilitate more active participation in politics. Information is used as a tool to measure the corporate image of nations and segregate the 'haves' (informed society) from the 'have-nots' (not informed society) and for strategic political formulation. Nations are now categorized according to how much premium they attach to and use information. This brought the slogan of "haves" and "have-nots' with one being at the other side of the information divide. Full participation in the political activities of any society especially democratically governed ones is inconceivable unless the people are empowered through genuinely free access to information (NDI 2003.). As a resource for human survival information has become so important that it has assumed the same status as land, labour and capital as production ingredients. FAO (1998) in Issa \& Sunday (2007) captures succinctly the characteristics of information that is germane to this study

1. they are oriented toward the needs of the user, incorporating the types and levels of information needed into the forms and language preferred by the user.

2. they use varied dissemination methods, including written information, electronic media, and person-toperson contact.

3. they include both proactive and reactive dissemination channels - that is, they include information that users have identified as important, and they include information that users may not know to request but that they are likely to need.

\subsection{Accessibility and Use of Political Information}

Accessibility to information is being able to use that particular information and only when political information is accessible to women can it be used appropriately for decision making. According to (FARN 2001) quoted by Kebede (2007)

“information has little value unless they are accessed when 
needed in a form they are needed. If access to existing information does not take place the potential benefits of possessing of information is lost. In other words the key to unleashing the benefits of information is effective access to them. As such access to information is recognized to be an instrument to help citizens to realize their own potential; to increase their skill, knowledge and capacity; and to take part in and benefit from the information society."

Harrop (2002) in examining the Human Right Instruments and the distribution of information, saw right of access to information as a vital component for the realisation of other rights. For example, without access to information on political parties, and the ability of political parties to express their opinions, a democratic voting system cannot operate. Article 25 of the ICCPR therefore talks about "guaranteeing the free expression of the will of the electors.

Various factors affect the accessibility of women to political information. They include the characteristics of the end user to information access. Characteristics of the end user are referred to as the qualities and capabilities that the women bring to information access point, this includes attitude of the women towards political information (Tung 2001).Negative attitudes of women towards the acquisition of political information hinge on the private/public dichotomy. That is, the perceived belief that political arena belongs to the men and women belong to the homes. This causes frustration that is further exacerbated by lack of interest and motivation to political integration.

Demographic factors also affect accessibility to political information like age, marital status, financial ability, income level versus the cost of acquiring needed information, belief system, cultural values, and educational level. Other factors include location (nearness) of the women to information sources, government regulatory policies which sometimes help to erode women independent initiative geared towards redemption from voicelessness, ignorance and powerlessness; and of course the channel through which this information gets to the rural women must be clear, unambiguous and uses the language they understand and trust.

Undoubtedly, access to political information is not only strategic but it is the foundation of participation of women in public policies that are aimed at them. Women are also partakers of the resources of the nation, how then should they be systematically excluded from the decision making process within the power structure? It is imperative that reliable, relevant and timely information be available to the women for adequate capacity information utilization in accurate policy decisions. U.N. report (2005) proposed that the African Union Constitutive Act should take the essential lead in championing the goal of universal access to political information as a prerequisite for achieving the Millennium Development Goal of gender inequality in political space. Nigeria has well-articulated policy commitments to achieving this index of MDGs but actual progress remains a challenge.

According to Wilson (2000) quoted from Babalola (2012), information use is the physical and mental act involved in incorporating acquired information into a person's existing knowledge base. It is the application of information in decision making. Utilization is an act of use. Information use is critical in decision making and studies have shown that successful use of political information can improve on responsiveness of government to her citizens and informed citizens can use political information to demand accountability from government. Put differently, information use helps people to understand the services they are entitled to and the mechanism available to them to demand this level of service (GSDRC).

Utilization of political information translates to proper understandability of the resources and situational impediments facing women in politics and transforming the knowledge into a workable vision. Political information use therefore becomes an activity to achieve political well-being of women in their participatory process. Political information will be more readily used from a source that is credible and trustworthy. Neither information access nor political participation are equally distributed across the population but the use of that information which is accessible makes for increase in the spectrum of possible political activities. Access and use of political information can be expected to bring with it an increase in the level of the information itself which in turn has a positive influence on participation. In other words, exposure to more information produces greater interest in politics and favours participation (Anduiza, Cantijock \& Gallego 2009).

Information distribution and delivery affect usage. From his review, O'Reilly (1983) evolved a number of propositions which offer rich possibilities on information use. He posited that information is more likely to be used by decision makers if it is readily understandable, relevant and from a source deemed as credible, that is trustworthy. Literature defines a credible source of information as that source that has experience and knowledge or information that comes from different sources and all the sources agree. Recent studies have established that the successful use of political information can improve on the responsiveness of government to her citizens and citizens can use information to demand accountability from government and that sustainable political information enabled strategies can lead to improvement on how government interacts with her citizens, ensure that citizens are informed about what their rights are, what government is doing, and what mechanism or options there are to seek redress when such rights are violated.

During the last decade evidences have accumulated that political information, when it is effectively processed and interpreted (used), contributes to good governance. For example, information use can contribute to improved governance by influencing opinion, attitude, and behaviour change of leaders and policymakers (political will), mid-level bureaucrats (organizational will), and citizens (public will) toward supporting governance reform objectives (Comm Gap at

(http://www.siteresources.worldbank/EXTGOVACC/Resourc es/Governancweb).

One characteristics of political information use is that 
participants become better acquainted with the subject matter. This helps initiate open-ended discussions that allow decision makers to understand the motivations, feelings, values behind women's opinions and understanding their attitudes, rather than measuring them. The women in turn become optimistic and open up in such fora. (NDI 2012).

Women use variety of information sources for political participation and most information sources are located in the urban areas which are too far for women to access given the fact that women are the concentrated poor people in the rural areas. Information networks are harder to build and sustain in rural areas where physical access is almost impossible due to bad roads, irregular transportation and poor infrastructure. This study sought to find out how easily the Niger Delta women can access political information from their geographical location, $(57.3 \%)$ and $(61.5 \%)$ respondents indicated that the distance from their abode to Electoral Commission and Party Secretariat was very far. The overall computation shows that majority of the women in the Niger Delta cannot access political information because their physical location is distanced from political infrastructures/activities which are mostly located in the urban areas out of the reach of the rural poor. The findings of (Issa 2007) reveal that the establishments and operations of agencies whose responsibilities are to ensure evenly widespread information dissemination in Nigeria have an orientation that is strongly urban-biased. Women in the rural areas face persistent structural constraints. The distance is further widened by bad roads, poor social networking, poor information infrastructures and low state presence. This indicates that women that live very far away from political venues/activities have limited access to political information. For women in the rural areas mobilization still poses a challenge at this point because routes to electoral wards are so remote. It becomes much costlier for coordination and communication for the women and makes it more difficult to initiate political information sharing among the women with distance as a factor. This has helped to impose limits and dictates the political opportunities available to women of the Niger Delta.

\subsection{Political Information Sharing as Catalyst for Women Political Participation in the Niger Delta}

The challenge of why women population power has failed to translate to political strength could be that the right information is not provided, understood, accessed, analyzed, used or adapted instead of commonalities in accusations that women lack political will. Kantumoya (1992) quoted from Kebede (2007) wrote:

People will not be able to get their due as citizens of present day society unless they have a continuous access to information which will guide them through and where necessary, the advice to help them translate that information into effective action, and unless they get their due, they are unlikely to recognize the reciprocal obligation that all citizens have to the society.

Access to political information maximizes the impact and long term benefits for women. Access to information is an empowerment tool that underpins democratic governance and which is also fundamental to other priority programme areas (UNDP 2003). It is important to raise awareness of rights to official information and strengthened mechanism to provide it especially to vulnerable group in the society. How do women in the Niger Delta access political information?

Table 3. Political information channels accessible to women of the Niger Delta

\begin{tabular}{|c|c|c|c|c|c|c|}
\hline & Channels & Very Easily Accessible & Easily Accessible & Accessible & Not Accessible & No Response \\
\hline (a) & Traditional Institutions & $\begin{array}{l}2698 \\
(57.4 \%)\end{array}$ & $\begin{array}{l}415 \\
(8.8 \%)\end{array}$ & $\begin{array}{l}554 \\
(11.8 \%)\end{array}$ & $\begin{array}{l}619 \\
(13.2 \%)\end{array}$ & $\begin{array}{l}412 \\
(8.8 \%)\end{array}$ \\
\hline (b) & Church/Mosque & $\begin{array}{l}1082 \\
(23.0 \%)\end{array}$ & $\begin{array}{l}760 \\
(16.2 \%)\end{array}$ & $\begin{array}{l}1783 \\
(37.9 \%)\end{array}$ & $\begin{array}{l}984 \\
(20.9 \%)\end{array}$ & $\begin{array}{l}89 \\
(1.9 \%)\end{array}$ \\
\hline (c) & Newspaper/Magazine & $\begin{array}{l}473 \\
(10.1 \%)\end{array}$ & $\begin{array}{l}392 \\
(8.3 \%)\end{array}$ & $\begin{array}{l}281 \\
(5.9 \%)\end{array}$ & $\begin{array}{l}540 \\
(11.5 \%)\end{array}$ & $\begin{array}{l}3012 \\
(64.1 \%\end{array}$ \\
\hline (d) & Public Library & $\begin{array}{l}54 \\
(1.2 \%)\end{array}$ & $\begin{array}{l}86 \\
(1.8 \%)\end{array}$ & $\begin{array}{l}63 \\
(1.3 \%)\end{array}$ & $\begin{array}{l}610 \\
(13.0 \%)\end{array}$ & $\begin{array}{l}3885 \\
(82.7 \%)\end{array}$ \\
\hline (e) & TV & $\begin{array}{l}546 \\
(11.6 \%)\end{array}$ & $\begin{array}{l}645 \\
(13.7 \%)\end{array}$ & $\begin{array}{l}711 \\
(15.1 \%)\end{array}$ & $\begin{array}{l}1899 \\
(40.4 \%)\end{array}$ & $\begin{array}{l}897 \\
(19.1 \%)\end{array}$ \\
\hline (f) & Women Groups and Associations & $\begin{array}{l}2467 \\
(52.5 \%)\end{array}$ & $\begin{array}{l}1059 \\
(22.5 \%)\end{array}$ & $\begin{array}{l}1036 \\
(22 \%)\end{array}$ & $\begin{array}{l}108 \\
(2.3 \%)\end{array}$ & $\begin{array}{l}28 \\
(0.6 \%)\end{array}$ \\
\hline (g) & Market Association & $\begin{array}{l}2006 \\
(42.7 \%)\end{array}$ & $\begin{array}{l}914 \\
(19.5 \%)\end{array}$ & $\begin{array}{l}717 \\
(15.3 \%)\end{array}$ & $\begin{array}{l}503 \\
(10.7 \%)\end{array}$ & $\begin{array}{l}558 \\
(11.9 \%)\end{array}$ \\
\hline (h) & Community centre & $\begin{array}{l}413 \\
(8.8 \%)\end{array}$ & $\begin{array}{l}401 \\
(8.5 \%)\end{array}$ & $\begin{array}{l}414 \\
(8.8 \%)\end{array}$ & $\begin{array}{l}998 \\
(21.2 \%)\end{array}$ & $\begin{array}{l}2472 \\
(52.6 \%\end{array}$ \\
\hline (i) & Interpersonal sources & $\begin{array}{l}3390 \\
(72.2 \%)\end{array}$ & $\begin{array}{l}908 \\
(19.3 \%)\end{array}$ & $\begin{array}{l}200 \\
(4.3 \%)\end{array}$ & $\begin{array}{l}112 \\
(2.4 \%)\end{array}$ & $\begin{array}{l}88 \\
(1.9 \%)\end{array}$ \\
\hline (j) & Radio & $\begin{array}{l}637 \\
(13.6 \%)\end{array}$ & $\begin{array}{l}851 \\
(18.1 \%)\end{array}$ & $\begin{array}{l}1818 \\
(38.7 \%)\end{array}$ & $\begin{array}{l}1279 \\
(27.2 \%)\end{array}$ & $\begin{array}{l}113 \\
(2.4 \%)\end{array}$ \\
\hline (k) & NGOs & $\begin{array}{l}2704 \\
(57.6 \%)\end{array}$ & $\begin{array}{l}822 \\
(17.5 \%)\end{array}$ & $\begin{array}{l}598 \\
(12.7 \%)\end{array}$ & $\begin{array}{l}378 \\
(8.0 \%)\end{array}$ & $\begin{array}{l}196 \\
(4.2 \%)\end{array}$ \\
\hline (1) & Posters & $\begin{array}{l}1305 \\
(27.8 \%)\end{array}$ & $\begin{array}{l}1173 \\
(24.9 \%)\end{array}$ & $\begin{array}{l}1189 \\
(25.3 \%)\end{array}$ & $\begin{array}{l}800 \\
(17.0 \%)\end{array}$ & $\begin{array}{l}231 \\
(4.9 \%)\end{array}$ \\
\hline
\end{tabular}




\begin{tabular}{lllllll}
\hline & Channels & Very Easily Accessible & Easily Accessible & Accessible & Not Accessible & No Response \\
\hline \multirow{2}{*}{ (m) } & \multirow{2}{*}{ Government publications } & 82 & 56 & 100 & 978 & 3482 \\
& & $(1.8 \%)$ & $(1.2 \%)$ & $(2.1 \%)$ & $(20.8 \%)$ & $(74.1 \%)$ \\
(n) & Internet & 76 & 41 & 255 & 1325 & 3001 \\
& & $(1.6 \%)$ & $(0.9 \%)$ & $(5.4 \%)$ & $(28.2 \%)$ & $(63.9 \%)$ \\
\hline
\end{tabular}

Respondents were asked how they accessed political information from these channels. Table 3 shows frequency with the very easily accessible channel through which information is accessed to be interpersonal sources (72.2\%) which include friends/relatives, passersby, peers, colleagues and lay experts followed by traditional institutions (57.4\%) including village heads, town criers, traditional festivals, folklore, dance etc.; NGOs (57.6\%), market associations $(42.7 \%)$, women groups and associations (52.5\%). Libraries as channel of information to the women ranked the least with $(1.2 \%)$, followed by internet $(1.6 \%)$. The few that cited TV $(11.6 \%)$, newspapers $(10.1 \%)$, posters $(27.8 \%)$ are women in the urban areas. Majority of the respondents, since we met them at their electoral wards are rural women who identified traditional institutions as the second major source that provide them with frequent political information. Obviously, the choice of traditional institutions as one of their major sources of information was influenced by their location.

From the responses not all available channels (sources) were accessible for various reasons including socio cultural factors, economic, educational qualifications and even location of residence. Studies have shown that the most common and trusted source of Nigerian women politicians is the interpersonal sources including women leaders/representatives who are the spokesperson for government. She relays and interprets government policies to the women using the language they understand and assists women in obtaining political information to optimize political outcomes. This finding is consistence with that of the Creative Commons CC (2012) whose study shows that women can be invited by friends to participate in politics. . Interpersonal sources as the highest rated information channel of political information to women supports the findings of Onwubiko (1996) who saw interpersonal sources as easy to access, highly persuasive and inexpensive and reliable.

Individual women access political information from other supplemental sources like mass media - radio (13.6\%). Every household visited had at least a small radio but was only used by the men. Radio ranked low among the sources of information dissemination to the women because the man would listen to radio in the evening while waiting for the wife to get the meal ready. She is not expected to listen to the radio until her chores are over for the night at which time she is tired and has little or no time to listen. TV (11.6\%) also was less preferred because of cost and incessant power cut in the rural areas but Hossain (2012) reported in his findings that mass media particularly television $(83.3 \%)$ ranked the highest most popular source of information dissemination among women in rural Bangladesh. Posters (27.8\%) was more preferred to other mass media as political information dissemination channel because posters were found even in remotest areas, newspapers/magazines (9.2\%) was so less preferred in the wards for inaccessibility because of remoteness and most importantly would rather use the money to buy food, government publications (1.8\%). Some added churches/mosques $(23.0 \%)$. Very few women indicated information accessibility through the internet (1.6\%) and library $(1.2 \%)$ which are located in the urban areas. According to Saleh (2011) wherever women find themselves whether in rural or urban areas they still have lower mobility than that of the men. The urban woman still cannot use the library or browse the internet for sake of family responsibilities. For the female students, they cannot even stay late to browse however pressing the need because women should not keep late nights.

The implication of this finding is that any information sent through the mass media will not get to majority of the women of the Niger Delta.

Political information sharing is highly orchestrated within the Nigerian polity. Women are allowed involvement in only a fraction of political activities and so information on these fractional activities is abundant and thus records heavy participation. For example, this study sought from the respondents their degree of use of different political information items to carry out their political activities in the Niger Delta

Table 4. Extent of Use of Political Information for Political Participation of Women of the Niger Delta.

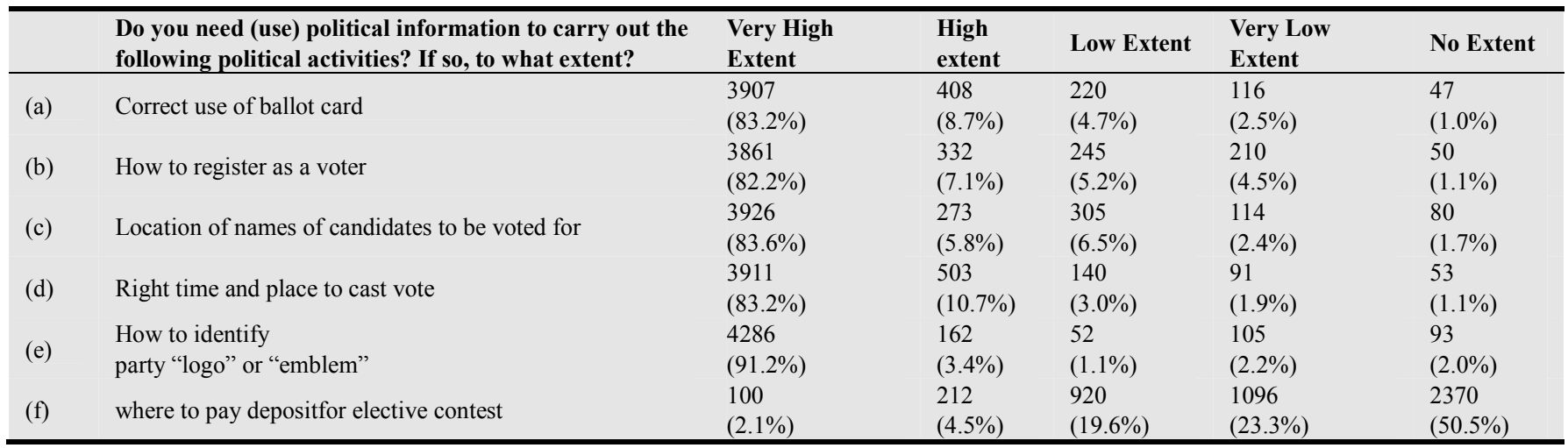




\begin{tabular}{|c|c|c|c|c|c|c|}
\hline & $\begin{array}{l}\text { Do you need (use) political information to carry out the } \\
\text { following political activities? If so, to what extent? }\end{array}$ & $\begin{array}{l}\text { Very High } \\
\text { Extent }\end{array}$ & $\begin{array}{l}\text { High } \\
\text { extent }\end{array}$ & Low Extent & $\begin{array}{l}\text { Very Low } \\
\text { Extent }\end{array}$ & No Extent \\
\hline (g) & How to raise funds for campaign & $\begin{array}{l}40 \\
(0.9 \%)\end{array}$ & $\begin{array}{l}52 \\
(1.1 \%)\end{array}$ & $\begin{array}{l}91 \\
(1.9 \%)\end{array}$ & $\begin{array}{l}1251 \\
(26.6 \%)\end{array}$ & $\begin{array}{l}3264 \\
(69.5 \%)\end{array}$ \\
\hline (h) & When to raise funds to organize political debates & $\begin{array}{l}125 \\
(2.7 \%)\end{array}$ & $\begin{array}{l}248 \\
(5.3 \%)\end{array}$ & $\begin{array}{l}365 \\
(7.8 \%)\end{array}$ & $\begin{array}{l}1100 \\
(23.4 \%)\end{array}$ & $\begin{array}{l}2860 \\
(60.9 \%)\end{array}$ \\
\hline (i) & Lobbying & $\begin{array}{l}644 \\
(13.7 \%)\end{array}$ & $\begin{array}{l}781 \\
(16.6 \%)\end{array}$ & $\begin{array}{l}798 \\
(16.9 \%)\end{array}$ & $\begin{array}{l}1203 \\
(25.6 \%)\end{array}$ & $\begin{array}{l}1272 \\
(27.1 \%)\end{array}$ \\
\hline (j) & When to engage in protests & $\begin{array}{l}973 \\
(20.7 \%)\end{array}$ & $\begin{array}{l}1219 \\
(26.0 \%)\end{array}$ & $\begin{array}{l}966 \\
(20.6 \%)\end{array}$ & $\begin{array}{l}790 \\
(16.8 \%)\end{array}$ & $\begin{array}{l}750 \\
(16.0 \%)\end{array}$ \\
\hline (k) & How to write petition & $\begin{array}{l}578 \\
(12.3 \%)\end{array}$ & $\begin{array}{l}481 \\
(10.2 \%)\end{array}$ & $\begin{array}{l}933 \\
(19.9 \%)\end{array}$ & $\begin{array}{l}1285 \\
(27.4 \%)\end{array}$ & $\begin{array}{l}1421 \\
(30.2 \%)\end{array}$ \\
\hline (1) & reason to participate in strike & $\begin{array}{l}1602 \\
(34.1 \%)\end{array}$ & $\begin{array}{l}847 \\
(18.0 \%)\end{array}$ & $\begin{array}{l}534 \\
(11.4 \%)\end{array}$ & $\begin{array}{l}1009 \\
(21.5 \%)\end{array}$ & $\begin{array}{l}706 \\
(15.0 \%)\end{array}$ \\
\hline
\end{tabular}

Results from the table 4 revealed unevenness in accessibility to political information. The utilization of available political information by the women to participate in various political events also existed but respondents gave leading positions to political activities that concerns how to make the women better voters. This is the only political category that political information is freely provided. They indicated they had more access to information dealing with voting in election, that is, registering as a voter in election, time and venue to cast vote, identification of party logo, correct use of ballot card and names of candidates to be voted for: with $(82.2 \%),(83.2 \%),(91.2 \%),(83.2 \%)$ and $(83.6 \%)$ respectively. Political analysts agree that voting in election remains the most participated electoral activity of voters in Nigeria. Even other scholars had similar discoveries in different parts of the world.

The value in the Table shows that information on how to identify party logo recorded $(91.2 \%)$. The highest extent of use of political information for party logo identification could be understood from ACE project (2007) findings that logos are important in countries with low literacy rates because they enable voters to identify their candidates or party. Party logos will therefore appeal to the illiterate women population $(34.7 \%)$ used in this study. They are just expected to memorize the emblem for voting. Information on how to raise funds for campaign $(0.9 \%)$ and how to raise funds for elective contest $(2.1 \%)$ were the least used information items.

The overall computation shows that most of the political information items used represent a fraction of political activities (that is information pertaining to voting only). Women need information to carry out all political activities but claim more knowledge about voting activities. They have more details and participate fully because this is the only category women are welcomed, accepted and expected to participate.

Since independence in 1960 women participation in Nigerian politics has been in the shadowy fringes, yet when it is time for election women are mobilized to vote. Women are considered only good for dancing after which they are given insignificant gifts like bags, Maggie cubes, small bags of table salt, boxes of matches etc. Although women are made to be key players at this electioneering activism, they are subject to exclusion from critical decision-making because the available information were more on those political information that empower the women to properly use their ballot cards, how to thump print correctly, when to cast votes, names of candidates to vote for, how to identify party logo

Akiyode-Afolabi (2011), Agbalajobi (1997) corroborated that women political participation is only voting which is a less demanding political activity. They are influenced by rigid mindset about women in politics, by inadequate political awareness, women are dogged by frivolous political scandal, fear, inferiority complex, husband's influence which dictates level of involvement, non-education, cultural predilections, religious belief, nature of Nigerian political environment which is hostile, coercion and intimidation, greater family responsibilities, deprivation of rights that have left women with fewer opportunities to acquire political experience, women lack political networks necessary for political successes and are constantly faced with precarious political situations, they lack resources to run campaigns so they are visible as candidates but lack adequate coverage, government failure to domesticate and implement International Conventions that promote women equal participation in policy and governance processes.

The lowest ranking to fundraising activities would mean that Nigerian women are economically vulnerable to vicissitudes of politics. They lack the resources to break into heavily monetized politics which characterizes the Nigerian political landscape leaving in its wake a strong institution of godfatherism which further subjugates them. The other political information items that concerned neither voting nor raising funds like lobbying $(13.7 \%$ ), when to engage in protests $(20.7 \%)$, how to write petitions $(12.3 \%)$, scored mixed results since the women use such political information items sparingly.

Respondents indicated mixed use of political information for participation in this last category because sometimes they are checked by cultural definitions. Most political meetings that engage in execution of these political activities are nocturnal and women participation is laced with frivolous gossips with discriminatory undertones. Women again cannot attend political functions (like lobbying) even in the day because of family responsibilities. It is absolutely odd for a woman, whether in urban or rural area to mobilize people for protests when she should be taking care of the home front.

The implication of these findings is that Women are exposed to the use of political information pertaining to 
theoretical knowledge only without exposing them to the skills of negotiating political relations which undermines true democracy. Secondly this condition further enhances continued marginalization of women from other political activities thus leading to the dominance of the political structure of the state apparatus by men.

\section{Research Methodology}

\subsection{Research Design}

This study adopted a descriptive survey research design of correlational type. Descriptive survey research design assists in the empirical interrelatedness of the variables under study. The variables are information access and use for women political participation. Descriptive Survey research design was also selected because it allows for administration of questionnaire for quality data collection and allows inferences to be made from the data from the field survey

\subsection{Scope of the Study}

This study will focus on political information accessibility, utilization by women in the Niger Delta which comprises the nine oil producing states of Nigeria. Other states of the Federation are therefore not included in this study. It covers all women of working age; that is women that are 18 years and above irrespective of their marital status

\subsection{Sample and Sampling Technique}

Multistage sampling technique was used for such heterogeneous population to allow for good representation and unbiased data collection. The zones were first stratified along geographical location lines into three sections; Western Niger Delta; Central Niger Delta and Eastern Niger Delta. The population was divided into strata of women in politics in the three geopolitical zones of Niger Delta. From each of these zones, two states were randomly selected.

In each of the six states, record of registered female voters was derived from record of total registered voters in 2011 general election in the country. The multistage sampling technique was used to select a representative sample of women registered voters from 6 states of the Niger Delta region of Nigeria selected for the study. Also samples of electoral wards from each state were selected in proportion to the size of registered women in the state. This implies taking a population of registered women per state in relation to the number of electoral wards in the studied states.

Using probability proportionate size, a representative sample $(20 \%)$ of the electoral wards was taken from each state in relation to the size of the registered voters per state and $(5 \%)$ was used from the number of women per sampled electoral ward. This multistage sampling method was adopted because of the heterogeneous nature of the population of study.

Table 5. Female Population of Registered Voters in the six selected States of the Niger Delta and samples selected.

\begin{tabular}{lllllll}
\hline States & $\begin{array}{l}\text { No. of Women } \\
\text { RegisteredVoters* }\end{array}$ & $\begin{array}{l}\text { Electoral } \\
\text { Wards (EW) }\end{array}$ & $\begin{array}{l}\text { Sampled EW } \\
(\mathbf{2 0 \%})\end{array}$ & $\begin{array}{l}\text { Women } \\
\text { per EW }\end{array}$ & $\begin{array}{l}\text { No. of Registered } \\
\text { Women in sampled EW }\end{array}$ & $\begin{array}{l}\text { Sample size (5\%) of Total no. of } \\
\text { Women }\end{array}$ \\
\hline Abia & 740,596 & 192 & 38 & 3857 & 14,657 & 733 \\
AkwaIbom & 857,391 & 163 & 33 & 5260 & 17,358 & 869 \\
Bayelsa & 236,195 & 106 & 21 & 2228 & 4,679 & 234 \\
Delta & 950,028 & 224 & 45 & 4241 & 19,085 \\
Edo & 706,113 & 180 & 36 & 3923 & 14,122 \\
Rivers & $1,209,529$ & 317 & 63 & 3816 & 24,040 \\
Total & $4,699,852$ & 1,182 & 239 & 23,325 & 94,041 & 706 \\
\hline
\end{tabular}

*In each of the six states, record of registered female voters was derived from record of total registered voters using Kinoti's (2011) estimate that half or slightly over half of the registered voters in 2011 general election in the country were women. INEC does not disaggregate voters list for states, as a result the researcher selected half of the voters as given by INEC from each state as the sample population. However, where a fraction existed, the whole number was added to women.

\subsection{Research Instruments}

The questionnaire as the main instrument was used to collect data for the study supported by interview. The selfadministered questionnaire was given to respondents who could read and write and the non-self-administered questionnaire was given to respondents who could not read or write. Both questionnaires contained the same questions. Oral interview was also used. It was used on the women who could neither read nor write alongside the non-selfadministered questionnaire. The oral questions were same questions on the questionnaire. The women's responses were recorded on the questionnaire chart. However responses were not tape recorded. The Niger Delta region is fraught with political violence as recorded in daily news, fear of other social political vices like even daylight kidnappings (even in places of worship before the whole congregation) and so on. Amid these characteristics of high political violence which the Niger Delta polity is identified, women tended to avoid making comments on political issues or give information for fear of reprisals whenever they recognize that their opinion will be tape recorded.

\section{Conclusion}

Poor democracies are considered an indicator of lack of functional information systems. Women constitute $50 \%$ of Nigeria's population, yet they are excluded from their fundamental rights of partaking in the decision making process. Backed by national and international instruments for equal participation, strategic information dissemination measures will lead to empowering women and creating their 
ability to critically engage with the state and the society for a social change and gender equality. Aware that poor information literacy and inappropriate use of information incapacitates the ability of women in the development of their potentialities, changes in the present economic, social and political conditions of women must become an integral part of efforts to transform instituted structures and entrenched attitudes for promotion of larger freedoms. It becomes imperative for government and non-governmental organizations to through relevant information dissemination process provide equal conditions and opportunities for advancement of women in their participation in the decision making process that also affect their lives.

\section{References}

[1] ACEproject -The Electoral Knowledge Network (2007).Registration of political parties. Available at: http://aceproject.org/ace-en/topics/ei/eif/eif07/eif07a

[2] Adebowale, A. (2012) A Study of Women Attitudes Toward their Socioeconomic and Political Empowerment: Nigeria Women and National Development. Department of Sociology, Faculty of Social Sciences, University of Lagos.

[3] Ademiluyi, Isreal\&Ademola, S. (2010) Gender Analysis and Political Participation. Journal of Law and Psychology E/Africa Journal of Peace.

[4] Agbalajobi, T.A. (1997) Women's participation and the political process in Nigeria: problems and prospects. Department of Political Science. Redeemer's University, Ogun State.

[5] Akiyode-Afolabi, K.(2011) Nigeria's Electoral reforms and the prospects for women participation in the 2011 elections. The Women Advocacy Research and Documentation Centre (WARDC).

[6] Anduiza, E; Cantijock, M and Gallejo, M. (2009) Political participation and the Internet: A Field Essay. Information Communication and Society.vol 12 no 6.

[7] Anyanwu, E.U., Zander, E. and Oparaku, D (2011) Information needs of policy makers in Nigeria: The case of Imo State civil service. Library Philosophy and Practice.

[8] Arowolo, D \&Aluko, F.S. (2010) Women and political participation in Nigeria .European Journal of Social Sciences. Vol 14 no. 4

[9] Attoe, S.E. (2013) Problems militating against women in politics. Avalable at: http://www.onlinenigeria.com/nigerianwo

[10] Babalola (2012) Information on consumption of packaged foods among female academic staff in the Nigerian Universities. An unpublished Ph.D Dissertation. Babcock University.Illisan

[11] Bansar, David (2010) Human Right 'Linking ICTs, the rights to Privacy, of expression, and access to information. E/Africa Journal of Peace and Justice. 116

[12] Bari, Fazana (2005) Women Political Participation: Issues and Challenges. UN Report. Bangkok, Thailand.
[13] Bimber, B (1999) Information as a factor in congressional politics. Working Paper no. 7. MIT (1998) The internet and political transformation: Populism, Community and Accelerated Pluralism. Polity vol.31, no 1.

[14] Browne, Evie (2014) The Power relationship that political economy analysis forgot Executive Summary 25 - From Political Economy to Political Analysis. Available at: http://www.dlprog.org/opinions/gender-the-powerrelationship-that-political-economy-analysis-forgot.php

[15] Comm Gap (Communincation for Governance and Accountability Program). Available at: http://www.siteresources.worldbamk/EXTGOVACC/Resource s/Governanceweb

[16] Duke II, Joe (2010) The Dynamics of Women Participation in Democratic Politics and Sustainable Development in Africa. Journal of Sustainable Development in Africa.vol.12, No. 4.

[17] GSDRC (Government and Social Development Resource Centre) Access to Information and its constraints. Available at: http://www.gsdrc.org/go/topic-guide

[18] GSDRC Transparency and access to information. Available at: http//www.gsdrc.org/go/topic-guides/empowerment...).

[19] Harrop .E .W. (2002) Human Right and the distribution of information. Available at: http://www.libertyandhumanity.com/human

[20] Heynz, C.et al. (2010) Compendium of key Human Rights Documents of the African Union.4th ed. South Africa. 62 Iknowpolitics (2005) (International Knowledge Network of Women in Politics). Summary on e-Discussion on challenges for women in politics: the glass ceiling stereotypes in terms of portfolio assignments. Available at: http://iKNOWpolitics.o

[21] Irabor, F.O. (2012) Women's participation and performance in Nigerian politics. Konrad - Adenauer Stiftung

[22] Issa, A.A. \& Sunday, S.B. (2007) Facilitating good governance through effective information dissemination to the Nigerian rural populace. Available at: http://www.unilorin.edu.ng/publications/issa/Dr\%20Issa\%204. doc

[23] Iwara, F. U.(2010) Availability and accessibility as influence factors of HIV/AIDS information utilization among women in Cross River state of Nigeria. Ph.D Thesis unpublished. University of Ibadan

[24] Karp, J. A. and Banducci, S. A. (2008) When politics is not just a man's game: women's representation and political engagement. Department of Political Science, University of Exeter. 105-115

[25] Kasomo, D (2012) Factors affecting women political participation in electoral politics in Africa. International Journal of Psychology and Behavioural Science. vol 2 (3) 57-63

[26] Kebede, G. (2007) Information and communication management strategy development: A Toolkit for Agriculture and Rural Organisation. Available at: http://publications.cta.int/media/publications/downloads/1726 _PDF.pdf

[27] Kebede, G. (2007) Information and communication management strategy development: A Toolkit for Agriculture and Rural Organization. Available at: http://publications.cta.int/media/publications/downloads/1726 _PDF.pdf 
[28] Kinoti Katambi (2011) Nigeria's elections reflects slow progress for women AWID. Available at http:free2runonline.com.ng/?p=481. Accessed 7th February 2014.

[29] KinotiKatambi (2011) Nigeria's elections reflects slow progress for women AWID. Available at http:free2runonline.com.ng/?p=481. Accessed 7th February 2014

[30] Losindilo, E; Musa R. and Akaaro, R.R.J. (2010) Some factors that hinder women participation in social, economic activities in Tanzania. Arts and Social Science Journal vol. 224

[31] Lukas, R.C. (2011) Women and political participation in Nigeria: The imperative of empowerment. Department of Political Science.Nassarawa State University, Keffi. Journal of Social Science and Public Polcy.vol.3 24

[32] Michelitch, K. (2012) Beyond Voting: Temporal Proximity to Elections, Competitiveness and Political participation. Available at: mgape.files.wordpress.com/2013/.../michelitch_beyondvoting _120630.p...

[33] Mosdale, S (2003) Towards a framework for assessing empowerment. Paper prepare for the international conference, New Directions in Impact Assessment for Development: Methods and Practice, Manchester UK, 24 and 25 November. $2-22$

[34] Nabanech Satang (2014) The power of women's political participation in ECOWAS. Available at: http//www.afad.org/alfichiers/CommunicationSatangNabaneth .pdf

[35] National Development Institute (NDI) Citizenship Participation. Available at: http//www.ndi.org

[36] NDI Women in political participation. Available at: http://www.ndi.org/women-politicap-participation Niger Delta Development Initiative:Political definition of N-Delta (2003). Available at: http://www.vamguardngr.com/articles/2002/features/fell50920 03.html

[37] Nwosu et al (2012) Socio-cultural factors as correlates of women's participation in politics in Nigeria. International Journal of Environment, Ecology, Family and Urban Studies.(IJEEFUS).vol 2 Issue 429
[38] Omekwu, Charles O (2003). Information Technology fundamentals for Lawyers. Paper presented at staff seminar. Nigerian Institute of Advanced Legal Studies, Lagos. 1-28

[39] Opeke, R.O. (1984) Information consciousness as a factor in organizational decision making. The case of Ogun State Ministry of Education, Ph.D. Thesis, University of Ibadan, p. 124

[40] O'Reilly, C. A. (1983) The use of information in organizational decision making: a model and some propositions. Research in Organizational Behaviour, 5, 103139.

[41] Pande, R (2011) Can Informed voters enforce better governance? Experiments in low income democracies. Annual Review of Economics.vol 3. 215 - 237

[42] Powell, R. R \& Connaway, L.S. 2004. Basic research methods for librarians.- 4th ed. -Westport: Libraries Unlimited. 123161

[43] Said Shamsul Islam (2013) Afghan women and the elections in $2014 . \quad$ Available at: http://www.cordaid.org/en/blogs/Said_Shamsul_Islam/afghanwomen-and-elections-2014/

[44] Saleh, A.G. and Lasisi, F.I. (2011) Information needs and information seeking behaviour of rural women in Bornu State, Nigerian .Library. Philosophy and Practice. Available at: $\mathrm{http}$ ://digitalcommons.unl.edu/cgi/viewcontent.cgi?article=Shi rin, R.M.(2000) International Perspective on Gender and Governance Macmillan Press, Great Britain

[45] Tripp, A. M. (n.d.)New trends in women political participation in Africa. Available at: http://www.democracy.stanford.edu/seminal/AlliT

[46] Uhegbu, A. N. (2004) Influence of political information and utilization on participation of women in politics in Imo State, Nigeria. PhD Thesis. (Unpublished) 13-77

[47] UN (1995) Report of the Fourth World Conference on women: The Beijing Declaration and Platform For Action. Available at: UN1325/Beijingchpt.html

[48] Wieringa, S. et al. (2005) Empowerment beyond numbers: substantiating women's political participation. Available at: http://vc.bridgew.edu/jiws/vol7/iss2/8/ 